\title{
ОПЫТНО-ЭКСПЕРИМЕНТАЛЬНЫЙ ОБРАЗЕЦ ПРИЦЕПНОГО КАТКА СНЕГОУПЛОТНИТЕЛЯ
}

\author{
Игнатьев Андрей Дмитриевич \\ заведующий учебно-производственной базой \\ Алексеев Айтал Русланович \\ студент \\ Научный руководитель: Ноев Иван Иванович \\ к.т.н., доцент \\ ФГАОУ ВО «Северо-Восточный федеральный \\ университет имени М.К. Аммосова»
}

Аннотация: в данной статье рассматривается опытноэкспериментальный образец конструкции дополнительного оборудования, созданный в рамках выполнения НИОКР «Прицепной каток снегоуплотнитель», который создан на Испытательном полигоне СВФУ. При эксплуатации оборудования опытный образец показал преимущества катка снегоуплотнителя при подготовке качественного снегового покрытия треков.

Ключевые слова: прицепное оборудование, каток снегоуплотнитель, снеговые треки, полигон, зимние испытания.

\section{PILOT-EXPERIMENTAL SAMPLE OF A TRAILER SNOW COMPACTOR ROLLER}

Ignatyev Andrey Dmitrievich Alekseev Aital Ruslanovich Scientific adviser: Noev Ivan Ivanovich

\begin{abstract}
: this article discusses a pilot design sample of additional equipment created as part of the R\&D "Trailed roller snow Compactor", which was created at the NEFU Test Site. During the operation of the equipment, the prototype showed the advantages of a snow compactor roller in the preparation of high-quality snow covering tracks.

Keywords: trailed equipment, snow compactor rink, snow tracks, landfill, winter testing.
\end{abstract}


В 2017 году на базе Автодорожного факультета Северо-Восточного федерального университета имени М. К. Аммосова было принято решение о создании инновационного проекта - строительство универсального испытательного полигона автомобильных шин и транспортной техники в городе Якутске. Для этого проекта было образовано малое инновационное предприятие $\mathrm{OOO}$ «Испытательный полигон СВФУ». Основной целью проекта стало строительство универсального испытательного полигона на территории опережающего социально-экономического развития «Якутия».

Испытательный полигон предназначен для проведения технических испытаний и научно-исследовательской, инновационной, технической и методической деятельности, прежде всего, основных характеристик по повышению надежности и технической эксплуатации транспортных средств, а также сопутствующего оборудования, изделий и материалов к ним в арктических условиях.

Испытательный полигон начал свою работу в первый зимний сезон 2019 года. С 2017 года ведутся работы по созданию инженерной инфраструктуры. Полигон оснащён необходимыми трассами и площадками из снега и льда высокого качества.

Испытательный полигон представляет собой научно-производственную площадку с соответствующим техническим оснащением.

Построено 5 испытательных треков:

- прямой разгонный снеговой 800x30;

- криволинейный снеговой $800 \times 5$;

- криволинейный снеговой $1800 \times 5$;

- прямой ледовый $100 \times 30$;

- криволинейный ледовый 850x5.

При эксплуатации и содержании треков в условиях низких климатических температур используется прицепной каток уплотнитель для выравнивания и уплотнения снеговых поверхностей и подготовки снеговых треков полигона.

Снежный слой обязательно уплотняют на протяжении всего пути, что связано с повышенной проходимостью автомобиля по треку. Подготовленный снеговой трек должен выдержать напряженный зимний сезон и не прийти раньше времени в негодность.

Уплотнение слоя снега - задача важная и комплексная, которую осуществляют регулярно. Если уплотнять снег только непосредственно перед 
проведением испытаний, то это грозит разрушением полотна уже на первом этапе и срывом мероприятия. А поскольку в сезон снег может выпадать непредсказуемым образом, а порывы ветра усиливают неравномерность снегового покрытия, работы по уплотнению снега требует использования специального оборудования на определенном этапе технологических операций по подготовке и эксплуатации снегового полотна трека.

Уплотнение снегового покрытия (слоя) производиться при достижении толщины снега в 5-10 см. Прицепной каток для уплотнения снегового покрытия является составным элементом технической системы грузового автомобиля КАМАЗа или трактора и управляется водителем. Наибольшее уплотнение снегового покрытия вдоль трековых трасс производится в 10-20 проходов по одному следу.

Испытательный полигон разработал опытно-экспериментальный образец прицепного катка снегоуплотнителя.

Комплектация опытного образца катка снегоуплотнителя включает в себя:

1. Восемь шин $315 \times 70$ R22.5;

2. Ступица ЗИЛ 131;

3. Фаркоп;

4. Швеллер № 20;

5. Швеллер № 10;

6. Металлический лист 50 мм;

7. Профильная труба 50 мм;

8. Вырезанный образец моста ЗИЛ 131;

9. К Кепежные детали к основной раме катка;

10. Доски деревянные.

Для создания дополнительного оборудования были проведены расчетные и графические работы. Были проведены расчеты конструкции катка для обеспечения надежности и прочности. Был выполнен чертеж общего вида катка снегоуплотнителя (рис. 1). По чертежу определены габаритные размеры для всей конструкции в целом. 


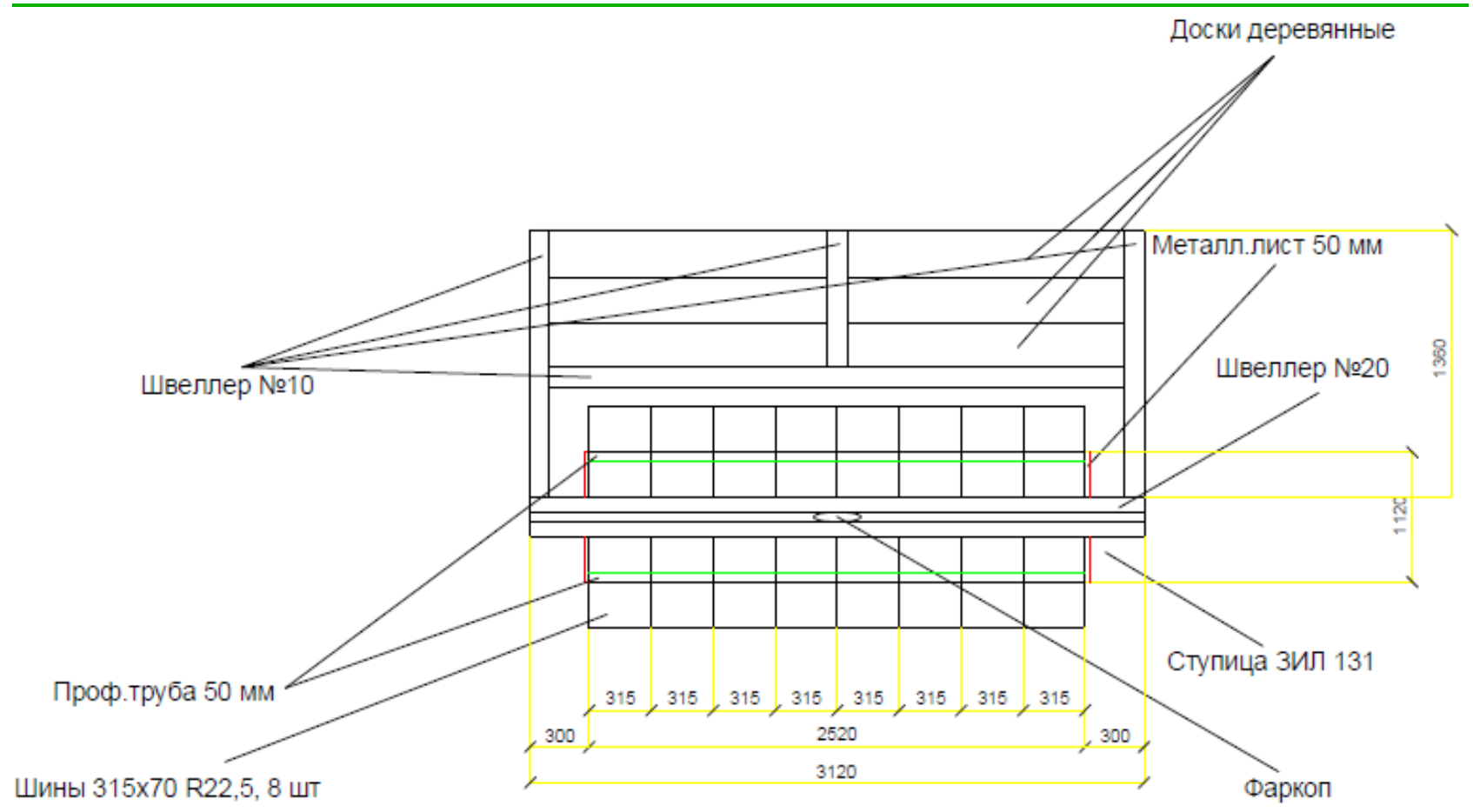

\section{Рис. 1. Общий вид катка снегоуплотнителя}

В катке снегоуплотнителя используются бывшие в употреблении грузовые автомобильные шины. Для катка снегоуплотнителя подходят летние, зимние покрышки в количестве 8 штук. Размер покрышек 315/70 R22,5. Ширина захвата - 2520 мм. Вес в сборе - 1500 кг.

Представленный экспериментальный образец катка снегоуплотнителя успешно используется на Испытательном полигоне при подготовке и эксплуатации снеговых треков. Эффективная работа на любом снегу, быстрая, удобная сборка, возможность использования грузовых шин диаметром 22,5 дюйма, все эти качества экспериментального образца катка снегоуплотнителя делают его незаменимым и производительным инструментом быстрой трамбовки снега после снегопадов.

Преимущества катка снегоуплотнителя: высокая скорость работы, большая ширина рабочего захвата не сдирает снег при малоснежье, хорошо укладывает большие количества свежевыпавшего снега, безопасен и прост в использовании экономит топливо и время.

Поставленная задача в рамках выполнения НИОКР - изготовление опытно-промышленного образца дополнительного прицепного оборудования 
«Прицепной каток снегоуплотнитель» (рис. 2) реализован на Испытательном полигоне СВФУ.

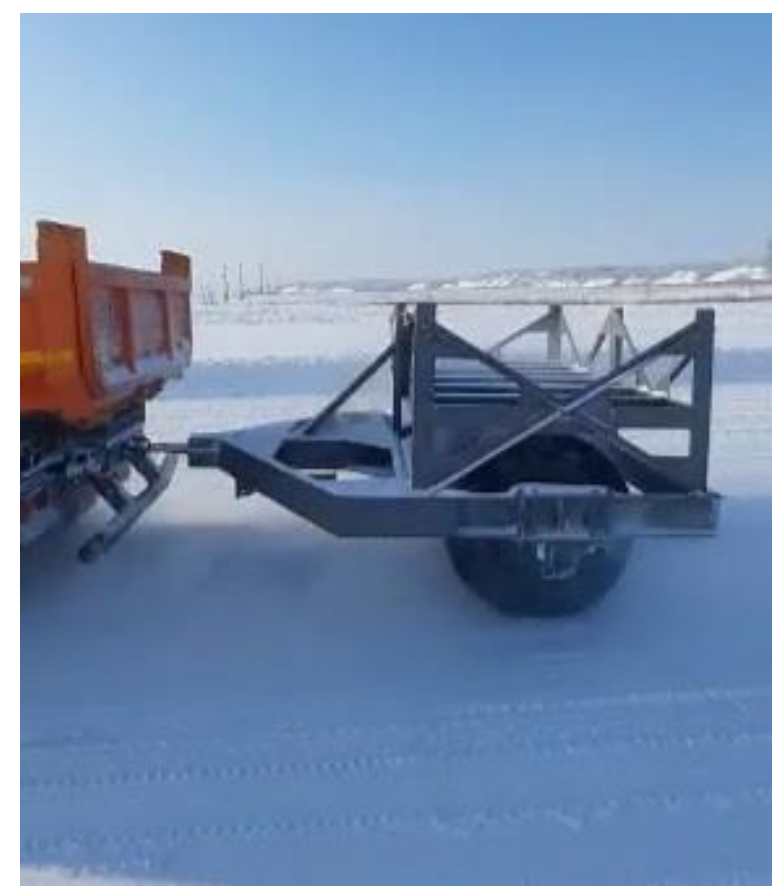

Рис. 2. Прицепной каток снегоуплотнитель

Стоит отметить, что университет уже много лет сотрудничает с японской корпорацией Bridgestone, которая в Якутске провела 13 испытаний, включая три экстремально низкотемпературных, ниже -45 градусов. Кроме этого, проверку морозоустойчивости своей продукции в суровых условиях Севера регулярно проводят производители техники и оборудования ведущие производители: японская корпорация Bridgestone, Федеральный испытательный центр «Вершина», АО «Автоваз», компании Bridgestone в России и СНГ.

\section{Список литературы}

1. ASTM F1805-06. Historical Standard. Стандартный метод испытания для измерения силы сцепления колеса, едущего по прямой линии на покрытых снегом и льдом поверхностях.

2. Филиппов Д.В., Ноев И.И. Инновационные решения в проведении тестовых испытаний и экспериментального сопровождения в условиях низких температур на базе универсального испытательного полигона СВФУ // Устойчивый Север: общество, экономика, экология, политика: сборник трудов $\mathrm{V}$ всероссийской научно-практической конференция (г. Якутск, 24-26 сентября 2019 г.). - Уфа, 2019. - Ч. 1. - С. 286-293. 
3. Филиппов Д.В., Ноев И.И. Реализация ключевых преимуществ Дальневосточного региона на примере Испытательного полигона СВФУ в ТОР «Якутия» // Климат-2020: современные подходы к оценке воздействия внешних факторов на материалы и сложные технические системы: материалы $\mathrm{V}$ Всероссийской научно-технической конференции (г. Москва, 10-11 сентября 2020 г.), [Электронный ресурс] / ФГУП «ВИАМ». - Москва, 2020. - С. 244-254.

(С) И.И. Ноев, А.Д. Игнатьев, А.Р. Алексеев, 2022 